\title{
Архивные документы по именованиям муниципальных образований Тувы (1759-2005 гг.)
}

\author{
Салимаа С. Ховалыг, Урана А. Даржа \\ Тувинский государственный университет, Российская Федерация
}

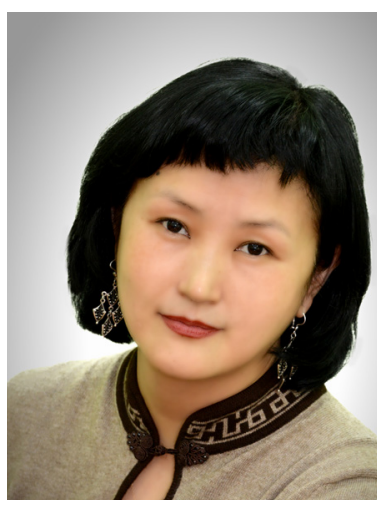

В статье проанализированы практически все документы Национального (до 07.04.2020 г. - Государственного) архива Республики Тыва, в которых встречаются упоминания названий муниципальных образований (их насчитано 49 ед.). Это документы управленческой деятельности органов местной власти и управления. Рассматривались происхождение наименований, а также вопросы их дальнейших изменений. Ретроспективный анализ формирования и эволюции муниципальных образований Тувы охватил документы с 1759 г. до 2005 г.

В качестве основной единицы муниципальных образований выделены муниципальные районы, в частности, административно-территориальные единицы Тувы, отдельные населенные пункты Тувы, начиная с впервые создававшихся в Туве поселений русских купцов до городов Кызыл, Чадан, Ак-Довурак, Шагонар, Туран.

В истории формирования и развития административно-территориального деления Тувы выделены четыре основных этапа: 1) 1759-1921 г2.; 2) 1921-1944 г2.; 3) 1944-1991 г2.; 4) с 1992 г. по настоящее время (2005 годом датирован последний проанализированный

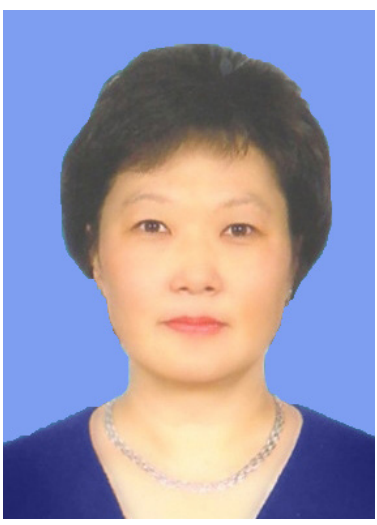
нами архивный документ). Документы первого этапа написаны на старомонгольском языке и оформлены по правилам китайского делопроизводства. Остальные документы на тувинском, русском языках.

Трансформация наименований некоторых муниципальных образований в Туве связывалась с административными реформами, государственным строительством, созданием или преобразованием на новый лад политических и социальных институтов. Происходило неоднократное районирование, которое приводило то к укрупнению, то к разукрупнению муниципальных районов, а также появлению новых административных центров. Переименования проводились в соответствие с принятыми на тот период языковыми нормами.

Ключевые слова: Тува; Урянхайский край; Тувинская Народная Республика; история Тувы; тувинский язык; старотувинский язык; архивный документ; муниципальное образование; административно-территориальное деление; топоним; хошун; сумон; арбан

\section{Для цитирования:}

Ховалыг С. С., Даржа У. А. Архивные документы по именованиям муниципальных образований Тувы (1759-2005 гг.) // Новые исследования Тувы. 2020, № 2. С. 103-119. DOI: https://www.doi.org/10.25178/nit.2020.2.7

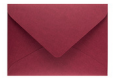

Ховалыг Салимаа Сергеевна - кандидат исторических наук, доцент, проректор по учебной работе и качеству, доцент кафедры всеобщей истории, археологии и документоведения, исторического факультета Тувинского государственного университета. Адрес: 667000, Россия, г. Кызыл, ул. Ленина, д. 36. Тел.: +7 (39422) 2-35-42. Эл. адрес: salimaa@mail.ru ORCID ID:0000-0002-2509-2402

Даржа Урана Анай-ооловна - кандидат филологических наук, доцент, директор Института довузовского образования, доцент кафедры русского языка и литературы, филологического факультета Тувинского государственного университета. Адрес: 667000, Россия, г. Кызыл, ул. Ленина, д. 36. Тел.: +7 (39422) 2-26-72. Эл. адрес: urana-63@mail.ru ORCID ID:0000-0002-1106-2384

Khovalyg Salimaa Sergeevna, Candidate of History, Vice-rector for Academic Affairs and Quality, Associate Professor, Department of General History, Archeology and Document Studies, Faculty of History, Tuvan State University. Postal address: 36 Lenin St., 667000 Kyzyl, Russian Federation. Tel.: +7 (39422) 2-35-42.E-mail: salimaa@mail.ru

Darzha Urana Anai-oolovna, Candidate of Philology, Director, Institute of Pre-College Education, Associate Professor, Department of Russian Language and Literature, Faculty of Philology, Tuvan State University. Postal address: 36 Lenin St., 667000 Kyzyl, Russian Federation. Tel.: +7 (39422) 2-26-72.E-mail: urana-63@mail.ru 


\title{
Archival documents on placenames of Tuvan municipalities (1759-2005)
}

\author{
Salimaa S. Khovalyg, Urana A. Darzha \\ Tuvan State University, Russian Federation
}

\begin{abstract}
The article analyzes almost every document found at the National Archives (prior to 07.04.2020 known as the State Archives) of the Republic of Tuva which mentions placenames of 49 Tuvan municipalities. These documents were originally drawn by local authorities and refer to their administrative practices. We examine the origin of these toponyms and their subsequent changes, with our retrospective analysis of the evolution of placenames of Tuvan municipalities covering the documents made between 1759 and 2005.

The list of municipalities includes the rayons of Tuva as the region's territorial units, and separate settlements, from those founded at the first arrival of the Russian merchants to the towns of Kyzyl, Chadan, Ak-Dovurak, Shagonar and Turan.

There are four stages in the rise and development of territorial division of Tuvan lands: 1) 1759-1921; 2) 1921-1944; 3) 1944-1991; and 4) 1992 to present, with the most recent document in our selection dated 2005. The documents written during the first stage appear in Old Mongolian and follow the rules of Chinese record keeping. Later documents were written in Tuvan or Russian.

Statebuilding, administrative reforms, and the creation or recreation of political and social institutions were the factors that helped change some of the Tuvan toponyms. The borders of the rayons were frequently changed, new rayons were created and then gave way to more recent ones, and new administrative centers appeared. Renaming followed the linguistic norms active at the moment.
\end{abstract}

Keywords: Tuva; Uriankhai Territory; Tuvan People's Republic; history of Tuva; Tuvan language; Old Tuvan language; archival document; municipality; territorial division; placename; hoshun; sumon; arban

\section{For citation:}

Khovalyg S. S. and Darzha U. A. Archival documents on placenames of Tuvan municipalities (1759-2005). The New Research of Tuva, 2020; 2: 103-119. (In Russ.). DOI: https://www.doi.org/10.25178/nit.2020.2.7

\section{Введение}

Из множества документов архивного фонда Национального архива Республики Тыва (Государственного архива Республики Тыва, ГА РТ) ${ }^{1}$ особый интерес представляют документы по именованиям муниципальных образований Тувы. Актуальность их изучения обусловлена необходимостью не только систематизации архивных документов по именованиям муниципальных образований, но и изучением истории формирования и развития административно-территориального деления Тувы. Эта тема также недостаточно изучена. Имеющаяся научная литература представляет собой труды российских исследователей и советских ученых - историков, этнографов, а также ученых по ономастике, освещающие именования географических объектов (гор, рек, озер, долин и т. д.). Наименования муниципальных образований предметом исследований до сих пор не становились.

Соответственно новизна данной статьи заключается в том, что впервые проанализированы практически все архивные документы главного архива Республики Тыва, в которых встречаются упоминания названий муниципальных образований. Новизна исследования также в его междисциплинарном характере.

Цель исследования заключается не только в выявлении типов и видов архивных документов, где встречаются упоминания о названиях местностей, но и в изучении происхождения наименований, анализе их дальнейшей трансформации. Ретроспективный анализ формирования и эволюции муниципальных образований Тувы охватил документы с 1759 г. до 2005 г.

\footnotetext{
${ }^{1}$ В связи с тем, что переименование архива пришлось на период предпечатной подготовки статьи (7 апреля 2020 г.) далее мы сохраняем в тексте старое название "Государственный архив Республики Тыва" и аббревиатуру "ГА РТ". - ред.

Editors' note: Since the Archives was renamed while editorial work on the article was already under way (April 7, 2020), we have preserved at some places the institution's old name - "State Archives of the Republic of Tuva".
} 
В качестве источниковой базы выступили документы ГА РТ таких фондов как: фонд 112 «Управление комиссара по делам Урянхайского края», охватывающие хронологические рамки с 1890 по 1919 гг., фонд 123 «Управление Заведующего устройством русского населения в Урянхайском крае» ${ }^{1}$ (1907-1921 гг.), которые являются ценными источниками по изучению именований первых русских поселений в Туве. По наименованиям времен Тувинской Народной Республики (1921-1944 гг.) нами были проанализированы фонды: 92 «Совет Министров ТНР» и 144 «Министерство внутренних дел ТНР». Именования муниципальных образований советского периода изучены по документам следующих фондов: 49 «Исполнительный комитет Дзун-Хемчикского районного Совета депутатов трудящихся», 264 «Исполнительный комитет областного Совета депутатов трудящихся Тувинской автономной области», 285 «Президиум Верховного Совета Тувинской АССР», 270 «Совет Министров Тувинской АССР», 362 «Исполнительный комитет Барун-Хемчикского районного Совета депутатов трудящихся». Современный период нами был проанализирован в результате изучения документов фонда 846 «Аппарат Законодательной палаты Великого Хурала Республики Тыва». Всего в общей сложности изучено 49 архивных документов.

Весь массив изученных архивных документов представляет собой первоисточники в виде документов, созданных в результате документирования управленческой деятельности органов власти и управления, созданные по правилам делопроизводства своей эпохи. Особый интерес представляют документы 1759-1921 и с 1921 по 1932 гг., написанные на старомонгольском языке и оформленные по правилам китайского делового документа.

Опираясь на документоведческие методы исследования, мы провели систематизацию архивных документов, обобщив их в системы организационно-правовых, распорядительных и информационносправочных документов.

В качестве основной единицы муниципальных образований мы выделили муниципальные районы, в частности, административно-территориальные единицы Тувы, отдельные населенные пункты Тувы, начиная с впервые создававшихся в Туве поселений русских купцов до городов Кызыл, Чадан, Ак-Довурак, Шагонар, Туран. В силу обширности хронологических рамок предмета исследования в ряде случаев мы были вынуждены ограничиться констатацией исторических фактов переименования отдельных населенных пунктов, вынеся более подробный лингвистический анализ для последующих исследований и публикаций.

\section{Научные исследования}

Российские исследователи и путешественники XIX века, изучавшие разные стороны жизни тувинских племен, оставили упоминания о наименованиях местностей, где располагались кочевья тувинских родовых групп.

Например, в труде Г. Н. Потанина, встречаются наименования реки Самагалтай (Потанин, 1883: 10) и другие именования местностей. Из административных названий встречаются именования хошунов и сумонов, Уинъ (Оюн), Сойонъ (Соян), Иргитъ (Иргит), Джоту (Чооду) и др., заимок русских купцов (Веселков) (Потанин, 1883: 10). В путевом дневнике известного ученого-тюрколога Н. Ф. Катанова также зафиксированы и географические названия Тувы, которые также как у других народов являются основными маркерами, так и названия хошунов и сумонов, происходящие от именований родовых групп, например, встречаются именования, ставшие впоследствии названиями муниципальных образований, Чакуль (русифицированное Чаа-Холь) (Катанов, 2011: 21-24). Также встречаются именования населенных пунктов русских купцов, например, «на устье Чакуля стоит заведение минусинского купца Е. П. Сафьянова » (там же: 21), прииски (Петропавловский прииск Гусева (по Серлику), Воскресенский прииск, зимовье Золотое (там же: 33), поселение Туран (там же: 39), Салдамское заведение А. П. Сафьянова (там же: 64). Наименование «Салдамское» Н.Ф. Катанов объясняет от слова «сал», что в переводе обозначает «плотик» и далее комментирует «Улу-Кем (Енисей) в этом месте весьма удобен для переправы на плотиках, которые зовутся у сойотов “сал” (там же: 71).

B трудах других путешественников, посетивших Туву в начале XX в., также упоминаются географические названия, наименования хошунов, сумонов, арбанов, русских заимок, приисков, зимовий. Это труды Г. Е. Грумм-Гржимайло, А. Д. Каррутерса, в которых встречается упоминание наименований

\footnotetext{
${ }^{1}$ Урянхайский край - наименование Тувы в официальных документах Российской империи в XVIII-XX вв.
} 
местностей, наименования мест расположения административных центров управления тувинскими племенами (Каррутерс, 1914: 159; Грумм-Гржимайло, 1926: 710; Грумм-Гржимайло, 1930: 10).

В целом труды ученых, исследовавших Туву в конце XIX - первом десятилетии XX в., посвященные этнографическому описанию тувинского этноса, изучению хозяйственного уклада, социальной организации, содержат многочисленные упоминания наименований административно-территориальных единиц, географических названий, наименования русских поселений. К характерным особенностям трудов этого периода можно отнести русифицированный вариант записи наименований, что также нами выявлено при анализе уже архивных документов.

Исследования ученых советского периода характеризуются анализом социальной структуры, описанием хозяйства, быта, материальной и духовной культуры тувинского народа. Из всех работ хотелось бы отметить фундаментальный труд В. А. Дулова, поскольку автор раскрывает возникновение и развитие русской торговли, золотопромышленности, промыслов в Туве и, следовательно, в работе имеется достаточно подробный перечень наименований русских поселений, заимок, приисков, торговых факторий (Дулов, 1956: 339, 343, 359). В частности, В. И. Дулов подчеркивает, что период прочного оседания русских крестьян на территории Тувы начался с 1885 г. - с образования русского поселка Туран (Дулов, 1956: 361), следующим поселением стал Уюк (Дулов, 1956: 362). Таким образом, наименования оседлых поселений в Туве связаны с переселением в Туву русских крестьян.

Фундаментальный труд Л. П. Потапова обобщает и уточняет исторические данные о тувинских племенах, территорию расселения тувинских родовых групп, и, следовательно, также содержит этнические именования, исторические названия географических объектов (Потапов, 1969: 43-78).

Иную группу работ составляют труды по топонимике Тувы, в основном являющиеся результатом исследовательской работы ученых-филологов: Ш. Ч. Сата (Сат, 1969: 232-234), Б. И. Татаринцева (Татаринцев, 1973, 1977 , 1993). М. В. Бавуу-Сюрюн, В. Бадарч (Бавуу-Сюрюн, 2005, 2018; Бадарч, Бавуу-Сюрюн 2018), Н. Д. Сувандии (Сувандии, 2019), Л. С. Кара-оол (Кара-оол, 2018, 2019аb).

Большой вклад в изучение топономии Тувы внесла Б. К. Ондар, на основе собранного фактического материала подготовившая и выпустившая два издания «Топонимического словаря Тувы» (2-е изд.: Ондар, 2007). Он включает в себя исторические и географические названия местностей по всей республике, с описанием происхождения, смыслового значения и правильного написания. Другие монографии автора: «Тувинская топонимика. Сопоставительное изучение топонимии Тувы с топонимией Южной Сибири и других тюркоязычных территорий» (Ондар, 2008), «Русская топонимия Тувы» (Ондар, 2011) - обобщают и уточняют исторические сведения о тувинских топонимах и появление русских географических наименований на территории Тувы.

Также необходимо отметить наличие отдельных работ, описывающих административно-территориальное деление Республики Тыва. Еще в советское время В. А. Дубровским и М. Ш. Кууларом для справочника-путеводителя по фондам ЦГА РТ, изданного в 1987 г. (Путеводитель ..., 1987) была подготовлена статья по административно-территориальному делению Тувы (там же: 182-188). М. Ш. Куулар затем работу дополнил и включил в качестве приложения в путеводитель по фондам Государственного архива Республики Тыва за 1715-2011 гг. (далее - Путеводитель) (Путеводитель ... , 2012: 346-363).

Сотрудники ГА РТ Т. Н. Биче-оол и А. А. Допчут недавно описали изменение границ административно-территориальных единиц Тувы в разные исторические этапы (Биче-оол, Допчут, 2015). В статье анализируется в первую очередь тема изменения территориальных границ районов.

Таким образом, кратко охарактеризовав труды исследователей, ученых, изучавших этнографические, исторические и языковые особенности тувинского народа, подчеркнем, что архивные документы по наименованиям муниципальных образований Тувы еще не являлись предметом научного исследования.

\section{Наименования первых муниципальных образований в 1759-1921 22.}

В истории формирования и развития административно-территориального деления Тувы можно выделить четыре основных этапа: 1) 1759-1921 гг.; 2) 1921-1944 гг.; 3) 1944-1991 гг.; 4) с 1992 г. по настоящее время. Нами условно обозначен в качестве конечной даты анализа 2005-й г., поскольку именно этой датой обозначен последний проанализированный нами архивный документ.

Первый этап выделен в связи с нахождением Тувы в составе империи Китая маньчжурской династии Цин, завоевавшей в середине XVIII в. соседние территории. Во всех подчиненных маньчжура- 
ми регионах, в том числе в Туве, были проведены административные реформы, которые заменили прежние территориальные устройства. С целью закрепления власти императора на вновь завоеванных землях Тувы была проведена административная реформа, преобразовавшая княжеские уделы в хошуны $^{1}$ - военизированные административно-территориальные единицы (Ховалыг, 2006). Хошуны были разделены на сумоны ${ }^{2}$, а сумоны состояли из арбанов ${ }^{3}$ В случае необходимости один арбан должен был выставить в солдаты 10 мужчин в возрасте от 18 до 60 лет (Липовцев, 1828: 100), а один сумон - 150 всадников в полной боевой экипировке. Шесть сумонов образовывали один полк, пять полков составляли дивизию, а пять дивизий - корпус (Бруннерт, Гагельстром, 1910: 371 ). В 1759 г. тувинские племена были разделены на четыре хошуна: 1) Тесийнгольский (Тес-Хемский, Оюннарский); 2) Хемгольский (или Салчакский); 3) Тоджинурский (Тоджинский); 4) Хубсугульский (Хасутский) (Потапов, 1969: 38-39). В 1764 г. в результате раздела тувинских племен, подчиненных монгольскому князю, между его сыновьями было образовано еще два хошуна: Даа (Хемчикский) и Бээзи. Управление Даа (Хемчикским) хошуном было передано Бугуде-дарга амбын-нойону, а Бээзи хошун остался под властью монгольского князя. В 1878 г. Хубсугульский хошун был переименован в Хасутский и перешел под непосредственное управление цзяньцзюня в Улясутае (Потанин, 1883: 12). Кроме упомянутых шести хошунов были еще тувинские хошуны, входившие во владения северомонгольских князей (Маады-Чооду, Шалык-Сартул), а также хошуны тувинцев, кочевавших в Монгольском Алтае, управлявшиеся наместником императора, находившегося в г. Кобдо (Ховалыг, 2019: 761-770).

Первый этап характеризуется также освоением Тувы русскими купцами, золотопромышленниками, первыми переселенцами. В 1885 г. появляется русское поселение Туран, выросшее из хозяйства Г. П. Сафьянова, получившего от генерал-губернатора Восточной Сибири Игнатьева разрешение на занятие земледелием, а также от тувинских чиновников (Дулов, 1956: 361). Районами русских поселений являлись Турано-Уюкский и Подхребиинский (Элегестинский) районы. Русское население проживало и на Тодже, занимаясь охотой и рыболовством. В Салчакском кожууне проживали в основном староверы. К первым русским населенным пунктам относятся Туран, Уюк, Знаменка (Сарыг-Сеп), Бай-Хаак и др. Русские переселенцы придерживались православия, но многие были старообрядцами. Последние жили в верховьях Енисея, Ильинке, Владимировке и др. В 1914 г. было начато строительство Белоцарска как административного центра (ставшего впоследствии столицей республики, ныне - г. Кызыл). Завершается период не только ростом числа русских поселков в Туве, но и созданием суверенного государства - Тувинской Народной Республики в 1921 г.

В фондах ГА РТ по данному этапу нами выделено 7 документов, из которых 2 относятся к распорядительным документам и 5 - к информационно-справочным. Документы оформлены на русском языке с использованием шрифта кириллического алфавита до реформы русской орфографии 1918 г.

Распорядительные документы:

1. Приговор № 2564 от 17 декабря 1918 г. Об утверждении нового посёлка «Пестуновский» (ГА РТ, ф. 123 , оп. 3, д. 349, л. 4). Документ оформлен на официальном бланке Комиссара по делам Урянхайского края, подписан секретарем;

2. Об утверждении Капкайского общества. 25 февраля 1919 г. (ГА РТ, ф. 123, оп. 3, д. 344, л. 6).

Информационно-справочные документы:

1. Сведения о расстоянии от всех населенных мест Урянхайского края и Усинского Пограничного Округа до г. Минусинск, по новостроящейся колесной дороге. 1 января 1916 г. (ГА РТ, ф. 123, оп. 1, д. 3, л. 60, 60об.),

2. Сведения о расстоянии населенных пунктов до Вилан (Белоцарска). Апрель 1916 г. (ГА РТ, ф. 123, оп. 1, д. 3, л. 60-61),

3. Сведения о расстоянии от всех населенных мест Урянхайского края до г. Белоцарска. 1 января 1916 г. (ГА РТ, ф. 123, оп. 1, д. 3, л. 60-64),

\footnotetext{
${ }^{1}$ Хошун (монг.), кожуун (тув.) - в современном тувинском языке слово в форме кожуун по-прежнему используется для обозначения муниципального района.

${ }^{2}$ Сумон (тув. суму) - в современном тувинском языке слово сумон, суму используется для обозначения сельского поселения.

${ }_{3}^{3}$ Арбан (монг.) - десяток, десятидворки, здесь: мелкая единица военно-административного деления. В тувинских арбанах дворов было более 10, иногда и более 20.
} 
4. Список поселков урянхайского края. Апрель 1918 г. (ГА РТ, ф. 112, оп. 1, д. 84, л. 2),

5. Переписка временно исполняющего обязанности Комиссара по делам Урянхайского края Заведующему устройством русского населения в Урянхае относительно отделения Маймазинского поселка от поселка Владимировки от 5 октября 1918 года (ГА РТ, ф. 123, оп. 3, д. 386, л. 3-3об.).

В архивных документах указаны сведения по именованиям, обозначающим типы поселений: деревня -1 , зимовье - 1, хутор - 11, заимка - 1, прииск - 11, пар. - 5, мор. $-1, n .^{1}-1$, рудник - 7, мельница -1 , поселок -1 и населенные пункты без обозначения типов поселения -35 . Данные именования представляют большой интерес с исторической точки зрения, так как обладает насыщенной информативностью: поселок Пестуновский, деревня Моховская, зимовье Мохова, прииск Наш и др. (ГА РТ, ф. 123, оп. 1, д. 3, л. 60-64; ф. 112, оп. 1, д. 84, л. 2; ф. 123, оп. 3, д. 386, л. 3-3об.; ф. 123, оп. 3, д. 349, л. 4). В документе, датированном апрелем 1918 г. «Список поселков урянхайского края» даны названия 7 районов: Подхребетинский, Мало-Енисейский, Туранско-Тарлыкский, Точжинский, Центральный, Чахульско-Шагонарский, Кемчикский и Прииска, а также 44 поселков (ГА РТ, ф. 112, оп. 1, д. 84, л. 2).

В документах отмечены именования поселений, имеющие тюркское и тюрко-монгольское происхождения. Наименование этих поселений связано не только с названием ближайшего географического маркера (горы, озера, реки и др.), но и зависит от того, являлась ли данная территория традиционным местом расположения той или иной родовой группы тувинских племен. Именования муниципальных образований, имеющих славянское происхождение, обнаруживают прямую связь с историческими этапами освоения Урянхайского края.

Топонимия тюркского, тюрко-монгольского происхождения в некоторых архивных документах сохранена в неискаженном виде: Туранъ (ГА РТ, ф. 123, оп. 1, д. 3, л. 60-60об.; ф. 123, оп. 1, д. 3, л. 60-61), Барыкъ (ГА РТ, ф. 112, оп. 1, д. 84, л. 2), Элегест, Шан, Туран (ГА РТ, ф. 112, оп. 1, д. 84, л. 2). В некоторых архивных документах подвергнута переоформлению (в русской речи) Бегреда, Amыхъ-Taшъ, Tanca, Уюкъ, Одчжа, Тарлыкъ, Оинъ-Шива, Чжакуль, Боянколь, Шагонаръ, Сестерга, Чженагашъ, Ута, Сейба, Карагашъ, Озеро Тере-Куль (ГА РТ, ф. 123, оп. 1, д. 3, л. 60-60об.; ф. 123, оп. 1, д. 3, л. 60-61), Джиданъ, Иниталъ (ГА РТ, ф. 112, оп. 1, д. 84, л. 2), Бегреда, Тапса, Уюкъ, Оджа, Оинъ-Шива, Чжакуль, Боянколъ, Атыхъ-Ташъ, Шагонаръ, Сестерга, Чжингашъ, Ута, Сейба, Карагашъ, Систикемъ, Хамсара, озеро Тере-Куль (ГА РТ, ф. 123, оп. 1, д. 3, л. 60-64); Бегреда, Уюк, Тарлык, Оин-Шива, Точжа, Сейба, Карагаш, Ут, Булук, Ирбек, Баингол, Шагонар, Тарлык, Ходжей, Чахуль, Туранско-Тарлыкский, Точжинский, Чахульско-Шагонарский, Кемчикский (ГА РТ, ф. 112, оп. 1, д. 84, л. 2), Кашпайск (ГА РТ, ф. 123, оп. 3, д. 344, л. 6).

В образовании наименований славянского происхождения существенная роль принадлежит антропонимам, которые выполняют не только назывную функцию, но и информационную. Они сообщают об именах или прозвищах основателей, о принадлежности данного поселения кому-либо: Лопатина, Щербаковка, Губановка, Сватикова, Колодкинб, Атамановка, Мозгалевскаго, Щербаковка, Федоровка, Медведевка, Бояровка, Знаменка, Хлебниковъ, Спрыгинъ (ГА РТ, ф. 123, оп. 1, д. 3, л. 60-60об.); Пестуновский (ГА РТ, ф. 123, оп. 3, д. 349, л. 4). С некоторыми изменениями и дополнениями: Губанова, Колодникъ, Лейзерович (ГА РТ, ф. 123, оп. 1, д. 3, л. 60-64); Максимовка, Владимировка, Даниловка, Мокеевка, Медведевка, Хлебниковский, Чихачевский (ГА РТ, ф. 112, оп. 1, д. 84, л. 2).

В исследуемых документах отмечены следующие именования муниципальных образований:

- производные от фитонима: Сосновка (ГА РТ, ф. 112, оп. 1, д. 84, л. 2);

- совмещающие понятия религиозно-культовых представлений первых переселенцев и ориентированности на местности по направлению течения реки, образование топонимов с помощью ориентировочных слов Нижний и Верхний с выделением пространственной информации: Н.-Никольский и В.-Никольский (ГА РТ, ф. 123, оп. 1, д. 3, л. 60-64);

- отражающие исторические реалии: Белоцарск (ГА РТ, ф. 123, оп. 1, д. 3, л. 60-61);

- характеризующие физико-географические свойства объекта: Грязнуха (ГА РТ, ф. 112, оп. 1, д. 84, л. 2);

- совмещающие понятия, производные от гидрономов и ориентированности на местности по направлению течения реки: В.-Усинское (ГА РТ, ф. 123, оп. 1, д. 3, д. 60-64);

${ }^{1}$ «пар., мор., пр.» - распространенные сокращения типов поселений, встречающиеся в архивных документах. «Пр.»- «прииск», «пар.»- может быть «паром», «мор.»- может быть искаженное от «маральник» - хозяйство, где выращивались маралы. 
- именования с указанием на тип поселения: «хутор» (Хутор Иванова, Хутор Вахрушева, Хутор Семена Михайлова и др.), заимка (Смолина), «прииск» (Воскресенский, Железнова и Сафьянова, Иннокентьевский и др.), пар. (Чирковой), мор. (Ведерникова), пр. (Муравьевой), «рудник» (Сергиевск. Иваницкаго, Отрадный Леонова, Метеоритный и др.), «мельница» (Полухина), встречающиеся в распорядительных документах Переселенческого управления ${ }^{1}$ (ГА РТ, ф. 123, оп. 1, д. 3, л. 60-60об.; ф. 123, оп. 3, д. 349, л. 4; ф. 123, оп. 1, д. 3, л. 60-64; ф. 112, оп. 1, д. 84, л. 2). В топонимах данной группы во второй их части выделяются антропонимы, которые указывают на фамилию первопоселенца или владельца. Интересно отметить, что антропонимы в основном относятся к лицам мужского пола, и только 2 - женского (Чиркова, Муравьева) (ГА РТ, ф. 123, оп. 1, д. 3, л. 60-64; ф. 112, оп. 1, д. 84, л. 2; ф. 123, оп. 3, д. 386, л. 3-3об.).

Так, данные архивных документов показывают, что к первому этапу формирования административно-территориального деления относятся архивные источники, в большинстве своем имеющие информационно-справочный характер. Эти документы в полной мере сохраняют и передают названия хошунов, сумонов, арбанов, районов, поселков, заимок, приисков, что является отражением социокультурных трансформаций, происходивших в традиционном тувинском обществе в конце XIX - первом десятилетии XX в. К первому этапу формирования административно-территориального деления относятся архивные источники, являющиеся распорядительными и информационно-справочными документами Переселенческого управления, канцелярии Комиссара по делам Урянхайского края. Названия поселений, заимок, приисков, арбанов, сумонов, хошунов, закрепленные в письмах и распоряжениях, отразили социокультурные трансформации, происходившие в традиционном тувинском обществе в конце XIX - первом десятилетии XX в.

\section{Наименования муниципальных образований в 1921-1944 22.}

Второй этап истории формирования и развития административно-территориального деления Тувы связан со временем становления и развития Тувинской Народной Республики (1921-1944 гг.). Это наиболее короткий по своим хронологическим рамкам этап в истории Тувы, но один из самых содержательных по достигнутым результатам в сфере социально-экономического и политического развития. Начало этапа ознаменовано официальным закреплением нового административно-территориального деления республики и наименований муниципальных образований на заседании Первого Великого Хурала ТНР, которое прошло 20 сентября 1923 г.

Именно в это время происходит трансформация наименований некоторых муниципальных образований в Туве, связанных с государственным строительством и с созданием или преобразованием на новый лад политических и социальных институтов. Однако следует подчеркнуть, что в эти годы происходило неоднократное районирование, которое приводило то к укрупнению, то к разукрупнению муниципальных районов, а также появлению новых административных центров.

Этап знаменуется переименованием некоторых поселений с русского, монгольского на тувинский язык. Также значительное влияние на наименование муниципальных районов, городских и сельских поселений оказал процесс создания тувинской письменности.

В результате дискуссий и обсуждений во время работы Первого Великого Хурала ТНР в 1923 г. было образовано шесть хошунов: Салчакский, Тес-Хемский, Тоджинский, Улуг-Хемский, Уюкский и Хемчикский. В территорию Хемчикского хошуна вошли Бейсэ и Даа хошуны. Все хошуны, кроме Салчакского, были переменованы по территориальному признаку (это название ближайшей реки, таежного массива и т. д., например, Тес-Хемский - от наименования р. Тес). Новое административное деление Тувы должно было способствовать развитию государственности и рационализации управления страной. Протоколы заседаний органов государственной власти и управления всех уровней свидетельствуют о том, какие проблемы преодолевались при формировании новых социальных, политических и экономических институтов. Например, с учетом дальности расстояний между хошунами в 1923 г. было принято решение о размещении ямских станций и выделении специальных должностных лиц и отдельного финансирования (ГА РТ, ф. 144, оп. 1, д. 1, л. 1-2). На заседании Второго Великого Хурала в 1924 г. Министерство внутренних дел отчиталось о выполнении поставленной задачи между хошунами были размещены 24 ямские станции (ГА РТ, ф. 144, оп. 1, д. 4, л. 9).

\footnotetext{
${ }^{1}$ Переселенческое управление - административный орган, обеспечивавший переселение и обустройство русских крестьян на территории Урянхайского края (1913-1919 гг.), руководил Переселенческим управлением Заведующий устройством русского населения в Урянхайского края.
} 
Итоги пятилетней работы по поиску наиболее оптимального распределения сумонов по хошунам и подбора соответствующих наименований муниципальных районов были подведены в 1929 г. В целом именно 1929 г. стал своеобразным маркером социально-политического развития ТНР, когда были подведены первые итоги и начат кардинальный поворот на путь борьбы со «старым» укладом жизни и представителями прежней аристократии в системе государственного управления. Выбранный путь к строительству новой Тувы в наименованиях административных единиц был закреплен осенью 1929 г., когда Президиум Малого Хурала заменил предыдущие наименования хошунов.

Переименование произошло по критерию замены прежнего названия на новое, выбранное в соответствии с названием такого географического объекта, который наиболее точно отражал расположение хошуна. Результат получился таким: Даа-хошун был переименован в Барун-Хемчикский, Бейсэ-хошун - в Дзун-Хемчикский. В этом мы видим восстановление древней традиции кочевых государственных образований, когда территория государства условно разделялась на восточную и западную части. Салчакский хошун получил тоже новое именование и стал Каа-Хемским; Оюннарский хошун - Тес-Хемским. Без изменения были оставлены названия Тоджинского и Улуг-Хемского хошунов.

В результате поиска наиболее оптимальных путей государственного управления 16 июня 1932 г. Совет Министров ТНР принимает решение о разукреплении Каа-Хемского хошуна на Бий-Хемский и Танну-Ольский хошуны, последний позднее был переименован в Тере-Хольский. Увеличение числа хошунов было обусловлено необходимостью выстраивания более стройной системы государственного управления, которая бы позволяла принимать решения и реализовывать поставленные задачи в области социально-экономического развития республики в более сжатые сроки. При прежней структуре административно-территориального деления расстояния между сумонами одного хошуна было значительным, то и доведение принятого решения до исполнения на местах было довольно затруднительным, именно в связи с дальностью расстояний внутри хошунов.

Архивные документы второго этапа характеризуются тем, что сначала они оформлялись на старомонгольском языке, а после декрета ТНР 28 июня 1930 г. стали вестись на основе ново-тюркского латинизированного алфавита (История Тувы, 2007: 270). Со второй половины 1930-х гг. начался массовый перевод письменности народов СССР с латинской на русскую графическую основу. В апреле 1941 г. XII съезд Тувинской Народно-Революционной Партии (ТНРП) принял соответствующее решение. Подготовка проекта новой письменности осуществлялась комиссией по языку и письменности, созданной при Совете Министров Тувинской Народной Республики. Ее членами стали А. М. Белек-Баир, С. С. Лопсан, Л. Б. Чадамба, А. М. Чымба, а руководил этой работой А. А. Пальмбах (там же: 271).

В фондах Государственного архива Республики Тыва к данному этапу нами выделено 9 документов, из которых 2 относятся к распорядительным документам, а 7 - к информационно-справочным, оформленных с использованием шрифта латинского алфавита.

Распорядительные документы:

1. Постановление Совета Министров ТНР за 1923 год, на старомонгольском языке. Архивный фонд «Органы государственного управления ТНР (Совет Министров ТНР)» (ГА РТ, ф. 144, оп. 2, д. 9, л. 20);

2. Постановление ЦК ТНРП о разукрупнении больших хошунов от 12 марта 1941 года, на старотувинском языке (ГА РТ, ф. 92, оп. 1, д. 915, л. 41-43; ГА РТ ф. 93, оп. 1, д. 229, л. 38-40).

Информационно-справочные документы:

1. Список административных единиц Тувинской Народной Республики на 1924 г. (ГА РТ, ф. 92, оп. 1, д. 11, л. 5-10);

2. Протокол Совета Министров ТАР от 16 июня 1932 г., на старомонгольском языке (Протокол № 6). (ГА РТ, ф. 92. оп. 1, д. 111, л. 38);

3. Сведения об административно-территориальном делении ТНР, на старотувинском языке, за 1934 г. (ГА РТ, ф. 92, оп. 1, д. 327, л. 24-25);

4. Отношение полномочного представителя ТНР в СССР в Совет Министров ТНР об уточнении названий населенных пунктов для составления новой географической карты ТНР за № 438 от 16 апреля 1935 г. на старотувинском языке (ГА РТ, ф. 92, оп. 1, д. 547, л. 2-4);

5. Наименование (название) всех сумонов и арбанов ТНР по состоянию на 1940 г. (ГА РТ, ф. 92, оп. 1, д. 849, л. 202-207);

6. Список названий поселков Тувинской Народной Республики от 30 октября 1943 г., в котором также имеется список названий хошунов, сумонов, хошунных и сумонных центров; на русском языке с использованием кириллического алфавита (ГА РТ, ф. 92, оп. 1, д. 1190, л. 3-5, 7-9); 
7. Список хошунных центров Тувинской Народной Республики за 1944 г., на старотувинском языке (ГА РТ, ф. 92, оп. 1, д. 1284, л. 2).

Список административных единиц Тувинской Народной Республики на 1924 г. (ГА РТ, ф. 92, оп. 1, д. 11, л. 5-10) представляет собой документ, отпечатанный с использованием кириллического алфавита, в котором практически все топонимы подвергнуты переоформлению и искажению. В связи с этим, очень сложно определить отнесенность того или иного именования к определенному топониму. Документ оформлен в виде таблицы, нами отмечено 5 хошунов, 55 сумонов, а также баки и арбаны: БаинХан-линский (Суткуль, Баин-охой, Херхэн-Ула, Хундерги, Хур-Дэга, Алтын-Саган-Абита, Баен-Журхэ, Баен-нур, Ак-Трк, Улаган-Агула, Акпедэк, Джаракко, Баен-Пата, Тылгыр-Шимтэ), Улан-Хан-Улун - /В.Кемч.) $)^{1}$ (Буин-Тогол, Сагали-Кол, Баен-нур, Иртыне-Булук, Буин-Дылыгр, Улаган-Тэга, Доле-Нур, БаенБайлак, Шай-кол, Иртыни-пата, Мунгун-Тайга, Ульзетэ-Хол), Жарагалатно.-Саган-арл. $\left.{ }^{2}\right)$, Ха-Хэмский (Иртыни-Булук, Хуху-Булук, Баен-Ельгис, Ульзэте-Бырхэ, Дылгырхан, Ириншин-хорло, Алтын-хан, Бурунхан, Уюк-хол, Абит., Баен-Ургун, Иртыни-илхым, Алтын-агула, Ивгельтышим, Буентс-Буггаса, Хендерге, Баенула, Таваста-Ула, Дыр-нур), тоженорский (Бейхем, Асес-Кол), тысэголский (Тысыгол, Жарагалатно, Баен-Вырхэ-Ула, Бурхонок-Гол, Хан-Ухуй, Баен-Ула, Ирсынгол).

Также в русском переводе текста протокола Совета Министров ТАР от 16 июня 1932 г. наименования хошунов и сумонов также подвергнуты переоформлению (в русской речи) следующим образом, $\mathrm{Xa-}$ Хемский хошун, Бей-Хемский, Танну-Ольский, Улук-Хемский (Улу-Хемский), Тесингольский, Тоджинский, Уюк, Баянгол, Систерлик, Ижим, Тоге, Ирбек, Брень, Копту, Тереколь, Элегест, Кок-Булук, Мочегей, Кызларик, Шурмок, Ижим. Отметим, что в основном все наименования относятся к топонимам тюркского происхождения, кроме двух: пос. Знаменка, пос. В.-Никольск. Именование восточного происхождения Туран сохранено в неискаженном виде (ГА РТ, ф. 92, оп. 1, д. 111, л. 38).

А в документе «Сведения об административно-территориальном делении ТНР» за 1934 г., оформленном на тувинском языке, с использованием латинской графики, отмечены наименования 9 кожуунов, 76 сумонов: Cөөn-xemcik (Xaajbrakkan, Cajlaq-alaak, Xөndergej, Solcur, Şemi, Corgaakkb, Xorum-taø, Xөlcyktyq, Syt-xөl, Xөr-tajga, Pajan-Tala, Teве-хаja, Ijme, Iziq-kara, Kbzbl-taq, Ak-turuq); Parbbn-xemcik (Kөp-seөk, Xol, Şuj, Kargb, M-puren, Saollb, Kara-xөl, Kbzbl-tajga, Ak, Xөndelen, Şekpeer, Ajangattb, E-parlbk, A- parlbk); Ulug-xem (Şagaan-arbo, Tus-taq, Xenderge, Iji-tal, Ezim, Temir-suๆ, Ejliq-xem, Yrbyn, Caa-xөl, Kara-tal, Xaajbrakkan, Kek-cbraa, Caattb); Tees-xem (Corgalandb, Paj-taø, Erzin, Narbn, Tees, Tere-xөl, Paj-xөl, O-şınaa, Ystyy-şbnaa, Perttaq, Şuurumak, Kaccbk); Pii-xem (Tarlaq, Өөk, Pajan-xөl, Eerbek, Sesserlaq, Tapsb); Kaa-xem (Pelbej, Pyren, Koptu, Kek-tej); Tandb (Mezegej, Kek-pulun, Eleges); Tozu (Toora-xem, Sbstbq-xem, Uluq-taq, Xam-sbra, Odygen); Tere-xel (Kargb, Tere-xөl, Palbktbq) (ГА РТ, ф. 92, оп. 1, д. 327, л. 24-25). В данном документе все именования тюркского или тюркско-монгольского происхождений.

Большая работа по реорганизации административно-территориального деления республики, связанная не только с уточнением именований муниципальных образований, но и с составлением географической карты Тувы началась с апреля 1935 г. Например, в архивном фонде Государственного архива Республики Тыва содержится документ, в котором поднимается вопрос об уточнении названий населенных пунктов для составления новой географической карты ТНР за № 438 от 16 апреля 1935 г. на старотувинском языке с использованием графики латинского алфавита (ГА РТ, ф. 92, оп. 1, д. 547, л. 2-4).

Также архивные документы «Наименование (названия) всех сумонов и арбанов ТНР по состоянию на 1940 год» (ГА РТ, ф. 92, оп. 1, д. 849, л. 202-207) и «Список хошунных центров Тувинской Народной Республики» за 1944 г. (ГА РТ, ф. 92, оп. 1, д. 1284, л. 2) оформлены на старотувинском языке с использованием латинского алфавита. В архивном документе 1940 года упомянуты 9 кожуунов и 82 сумона с тюрскими или тюрско-монгольскими корнями: Parbbn-Xemcik (Ak, Kbzbl-taף, Xөndelen, Kara-Xөl, Askb parlbk, Kөp sөөk, Xөl, Paital, Şuj, Ergi parlbk, Kargb, Ajangattb, Mөgen-pyren, Saqlb, Şekpeer), Pii-Xem (Pajankol, Sesserlio, Xyt, Tapsb, Tarlaø, Өөk), Tandb (Mezegej, Eleges, Kөk-pulun, Toka kyr-ekonom), Kaa-xem (Koptu, Pyren, Pyren-xem, Pelbej, Xaraal), Tozy (Toora-xem, Sbstbq-xem, Odygen, Uluq-taq, Xam-sbra), Tere-xөl (Kargb, Sbnaa, Palbktbo, Corgalandb ), Coөn-Xemcik (Ijme, Pajan-tala, Xer-tajga, Cadaana, Şemi, Ak-Turuø, Xөlcyktyø, Solcur, Pora-tajga, Xajbrakkan, Teве-хаja, Corgakkb, Xorum-taø, Syt-xөl, Kbzbl-tajga, Xөndergej, Kbzbl-taq), Uluq-xem (Şagaan-arbg, Xenderge, Tus-taq, Calaattb, Caattb, Caa-x, Kbzbl-tajga, Yrben, Xereme, Kara-tal, Ejliq-

\footnotetext{
${ }^{1}$ В.-Кемч. - сокращенное от «Восточно-Хемчикский».

2 Здесь в архивном документе видимо пропущена страница, поскольку нумерация сумона Жарагалатно-Саганарл (Чыргаланды) в документе отмечена за номером 10. Скорее всего это было сделано изначально, поскольку в нумерации листов пропусков не обнаружено.
} 
xem, Temir-suø, Ezim, Xajbrakkan, Kek-cbraa, Iji-tal), Tees-Xem (Cbrgalandb, Erzin, Narbn, Tere-xөl, Peert-tao, Terektio-xem, Ystyy-şbnaa, Paj-taq, O Şınaa, X-tees, Paj-xөl, Şuurmak) (ГА РТ, ф. 92, оп.1, д. 849, л. 202-207).

12 марта 1941 г. Президиум Малого Хурала ТНР за счет разукрупнения существующих образовал шесть новых хошунов: Бай-Тайгинский, Монгун-Тайгинский, Овюрский, Сут-Хольский, Чаа-Хольский и Эрзинский, соответственно в ТНР с 1941 г. всего 15 хошунов. Все новые наименования связаны с отличительным географическим объектом каждого хошуна (наименования гор, местности, озера, рек).

Архивные документы «Список названий поселков Тувинской Народной Республики» от 30 октября 1943 г. и «Список названий хошунов, сумонов и хошунных, сумонных центров» от 30.10.1943 (ГА РТ, ф. 92, оп. 1, д. 1190, л. 3-5, 7-9) содержат названия хошунов, сумонов в русской и тувинской транскрипциях. Данные архивные документы дают исследователям возможность каким-то образом упорядочить правописания, подвергнутые переоформлению (в русской речи), и идентифицировать названия хошунов и населенных пунктов, тем самым устранив создавшуюся путаницу в разночтениях, обозначенных на русском («старые названия») и тувинском языках, одних и тех же именований. В документах обозначены названия 15 хошунов и 83 сумонов. В частности, Комиссия по усовершенствованию литературного языка и письменности при Совете Министров ТНР в соответствии с установленными требованиями транскрибирования географических названий с языков тюркской группы на русский язык и с учетом картографической традиции, а также бытующего среди русского населения произношения тувинских географических названий установила следующие транскрипции названий хошунов на русском языке: Бай-Тайга, Барун-Хемчик, Бий-Хем, Каа-Хем, Монгун-Тайга, Сют-Холь (позднее транскрибированное в Сут-Холь), Тес-Хем, Улуг-Хем, Чаа-Холь, Чун-Хемчик (позднее Дзун-Хемчик), Эрзин (ГА РТ, ф. 92, оп. 1, д. 849, л. 202-207).

А в документе «Список хошунных центров Тувинской Народной Республики» за 1944 г. (ГА РТ, ф. 92, оп. 1, д. 1284, л. 2) дан список 15 хошуунов и их центров, а также город Кызыл.

Архивные документы данного этапа отражают процессы формирования и развития административно-территориального деления, завершившиеся не только преобразованием территориальных границ хошунов, но и уточнением их названий и на русском, и на тувинском языках.

\section{Наименования муниципальных образований в 1944-1991 г2.}

Третий этап (советский) рассматриваемого нами процесса начинается с вхождения ТНР в состав Советского Союза в 1944 г. и завершается в декабре 1991 г. в связи с распадом СССР. Процессы районирования региона менялись в связи с тем, что Тува сначала вошла в состав государства на правах Тувинской автономной области, и лишь в 1961 г. стала Тувинской АССР.

Административное деление Тувинской автономной области было произведено в соответствии с Конституцией РСФСР. В рамках унификации в процессе советизации тувинских административных единиц была проведена работа по переименованиям, в результате вместо хошунов были образованы районы, вместо сумонов - села. Преобразования коснулись не только наименований административных единиц, но и названий органов государственной власти и управления, например, хошунные, сумонные, арбанные малые хуралы трудящихся были преобразованы соответственно - в районные, сельские и арбанные советы депутатов трудящихся. Усилившийся процесс коллективизации сельского хозяйства сделал ненужным дробление сел на арбаны, и в 1947 г. они были упразднены.

Перевод тувинской письменности на русскую графическую основу завершился в 1945 г. Поэтому все документы данного этапа оформлены на русском языке.

Всего нами было изучено 32 документа, входящих в 49, 264, 285, 362 и 846 фонды ГА РТ. Проанализировано 29 организационно-распорядительных документов, из них указов -11 , постановлений -12 , решений -5 , законов -1 . Из 5 информационно-справочных документов -1 письмо, 3 сведения, 1 реестр; и один документ без наименования вида документа, содержащий заголовок к тексту документа «Заседание...».

Документы имеют следующие реквизиты: автор документа, наименование вида документа, дата и регистрационный номер документа, место издания документа, заголовок к тексту, текст документа, реквизит подпись, содержащий полное наименование должности лица, подписавшего документ.

По содержанию данные документы можно условно разделить на 4 группы:

1. Документы по административно-территориальному составу - 6 штук; 
2. Документы, определяющие изменения, переименования, преобразования административнотерриториальных делений и населенных пунктов - 8 штук;

3. Документы, утверждающие наименования населенных пунктов - 2 штуки;

4. Документы об образовании сельских Советов депутатов трудящихся и сумонов, кожуунов 16 штук.

K первой группе относятся распорядительные и информационно-справочные документы: Решение № 100 от 8 мая 1945 г. Исполнительного комитета Областного Совета депутатов Трудящихся Тувинской автономной области «Об административно-территориальном составе Тувинской автономной области» (ГА РТ, ф. 264, оп. 1, д. 20, л. 13-16), Указ Президиума Верховного Совета РСФСР от 7 августа 1945 г. «Об административно-территориальном составе Тувинской автономной области» (ГА РТ, ф. 264, оп. 1, д. 20, л. 13-16, 3-3об.); «Сведения об административно-территориальном делении Тувинской автономной области по состоянию на 1 августа 1958 года» (ГА РТ, ф. 264, оп. 1, д. 677, л. 20-27); «Сведения о датах основания городов Тувы» от 19 июля 1958 г. (ГА РТ, ф. 264, оп. 1, д. 677, л. 28).

В документе от 8 мая 1945 г. № 10 «Решение об административно-территориальном составе Тувинской автономной области» утверждено 15 именований районов (хошунов), из которых подвергнуты переоформлению (в русской речи) именования Сют-Хольский, Чун-Хемчикский, Бий-Хемский, сохранены в «частично-истинном» виде (истинное именование + суффикс русского языка -ск- и окончание -ий): Бай-Тайгинский, Барун-Хемчикский, Каа-Хемский, Монгун-Тайгинский, Овюрский, Тандынский, Тере-Хольский, Тес-Хемский, Тоджинский, Улуг-Хемский, Чаа-Хольский, Эрзинский. Именования 4-х городов: одно областного подчинения Кызыл и три районного (хошунного) подчинения Туран, Шаган-Арыг, Чадан, в которых два последних подвергнуты переоформлению в русской речи. Именования рабочих поселков также переоформлены в русской речи: Бай-Сют, Харал, Эми. В документе определены именования 15 районных центров в неизменном виде: село Кызыл-Мажалык, город Туран, село Сарыг-Сеn, село Мугур-Аксы, село Хандагайты, село Суг-Аксы, село Чыргаланды, село Самагалтай, село Чаа-Холь, село Сарыг-Булун, подвергнутые переоформлению (в русской речи) село Тэли, село Бай-Хак, село ТораХем, город Шаган-Арыг, город Чадан (ГА РТ, ф. 264, оп. 1, д. 20, л. 13-16).

$\mathrm{B}$ «Сведениях об административно-территориальном делении Тувинской автономной области», составленных по состоянию на 1 августа 1958 г., даны наименования 13 районов и районных центров, нет наименований Монгун-Тайгинского и Тере-Хольского районов и их центров. Уточнены правописания некоторых наименований районов и районных центров: Дзун-Хемчикский, Пий-Хемский, Сут-Хольский, Бай-Хаак, Тээли; наименование Шаган-Арыг еще раз подвергнуто переоформлению (в русской речи) и прописано как «Шагонар». Документ содержит наименование одного рабочего поселка - Хову-Аксы (ГА PТ, ф. 264, оп. 1, д. 677, л. 21-27). В документе от 19 июля 1958 г., уточняющем даты основания городов, даны именования Кызыл, Туран, Шагонар, Чадан (ГА РТ, ф. 264, оп. 1, д. 677, л. 28).

Вторая группа - распорядительные документы: Решение исполнительного комитета Овюрского районного совета депутатов трудящихся Тувинской автономной области от 30 марта 1950 г. № 38 «Об изменении административно-территориального деления некоторых сельских (сумонных) Советов района» (ГА РТ, ф. 264, оп. 1, д. 182, л. 81); Постановление Президиума Верховного Совета Тувинской АССР от 26 декабря 1964 г. «Об изменениях в административно-территориальном делении Тувинской АССР» (ГА РТ, ф. 285, оп. 1, д. 50, л. 288); Указ Президиума Верховного Совета Тувинской АССР от 27 декабря 1974 г. «О некоторых изменениях в административно-территориальном делении районов республики» (ГА РТ, ф. 285, оп. 1, д. 297, л. 383-385); Указ Президиума Верховного Совета Тувинской АССР от 3 декабря 1975 г. «О некоторых изменениях в административно-территориальном делении Тувинской АССР» (ГА РТ, ф. 285, оп. 1, д. 352, л. 280); Указ Президиума Верховного Совета Тувинской АССР от 16 марта 1988 г. № 21 «Об исключении из учетных данных некоторых населенных пунктов Улуг-Хемского района» (ГА РТ, ф. 285, оп. 1, д. 114, л. 118).

В Решении от 30 марта 1950 г. № 38 «Об изменении административно-территориального деления некоторых сельских (сумонных) Советов района» приведены наименования сумонных советов: Чалаатинский, Дус-Дагский, Хандагайтинский. В результате присоединения двух сумонных советов сохраняется наименование Дус-Дагский (ГА РТ, ф. 264, оп. 1, д. 182, л. 81). Постановлением Президиума Верховного Совета Тувинской АССР от 26 декабря 1964 г. «Об изменениях в административно-территориальном делении Тувинкой АССР» определены наименования 11 районов и их центров, подвергшихся переоформлению (в русской речи) и частично неизменном виде - Чадан, Тора-Хем, Шагонар, и в неискаженном виде - Тээли, Эрзин, Кызыл-Мажалык, Сарыг-Сеп, Хандагайты, Туран, Бай-Хаак, Сама- 
галтай, Ак-Довурак (ГА РТ, ф. 285, оп. 1, д. 50, л. 288). В указах Президиума Верховного Совета Тувинской АССР от 27 декабря 1974 г. «О некоторых изменениях в административно-территориальном делении районов республики», от 3 декабря 1975 г. «О некоторых изменениях в административно-территориальном делении Тувинской АССР», а также от 16 марта 1988 г. № 21 «Об исключении из учетных данных некоторых населенных пунктов Улуг-Хемского района» зарегистрированы вновь возникшие населенные пункты на территориях сельсоветов - 10 поселков: Тардан, Авыйган, Ужеп, Элдиг-Хем, Коп-Кежиг, Суг-Кажаа, Найырал, Магой, Суглуг-Хем и Терлиг-Хая. Исключены из учетных данных 19 населенных пунктов сельских советов как имеющие временный характер в связи с переселением и как попавшие в зону затопления: Аянгаты, Шыраа-Булак, Кудук, Малиновка, Сайлыг-Кара, Тайга, Базырылак-Адаа, Мажалык, Тейлер, Шат, Шивилиг, Ден-Терек, Алгыяк, Кулун-Дужер, Шеми-Аксы, Алдыь-Шынаа, Кок-Чыраа, Урбюн, Кара-Тал (ГА РТ, ф. 285, оп. 1, д. 297, л. 383-385; д. 352, л. 280, д. 114, л. 118).

К третьей группе относятся распорядительные документы. Решением Исполнительного комитета Дзун-Хемчикского районного Совета депутатов трудящихся Тувинской автономной области № 153 от 30 сентября 1959 г. «Об утверждении населенных пунктов Дзун-Хемчикского района» в состав 9 сельских советов входят 18 населенных пунктов, среди которых 4 наименования на русском языке, от названий производственных или промышленных предприятий конкретного направления:

- Кирсарай от «кирпичный сарай», т. е. здание, в котором производят кирпич, и территория с домами, в которых проживают рабочие данного завода;

- Угольный шахты, Инкубаторный станция - в именовании допущены ошибки в согласовании, должно быть: Угольные шахты, Инкубаторная станция. Также при написании Ст. искуственный осменения допущены орфографические и грамматические ошибки, должно быть: Станция искусственного осеменения;

- именование Чыра-Бажы, подвергшееся переоформлению в русской речи (ГА РТ, ф. 49, оп. 1, д. 102, л. 113-114).

Указом Президиума Верховного Совета РСФСР от 7 августа 1945 г. был утвержден новый административно-территориальный состав ТАО (ГА РТ, ф. 264, оп. 1, д. 20, л. 13-16, д. 23, л. 3-3об.). Как уже было ранее отмечено, статус городов получили три населенных пункта: Кызыл, Туран, Чадан, Шагонар; рабочих поселков - золотые прииски Бай-Сют, Нарын, Харал и Эми. Таким образом, территория Тувы была разделена на 16 муниципальных районов:

Бай-Тайгинский (центр - с. Тээли) в составе Бай-Тальского, Коп-Сокского, Тээлинского, Хольского и Шуйского сельсоветов;

Барун-Хемчикский (с. Кызыл-Мажалык) в составе Акского, Аксы-Барлыкского, Аянгатинского, КараХольского, Кызыл-Мажалыкского, Кызыл-Тайгинского, Хонделенского, Шекпээрского и Эрги-Барлыкского сельсоветов;

Дзун-Хемчикский (г. Чадан) в составе Баян-Талинского, Ийменского, Хайраканского, Хондергейского, Хорум-Дагского, Чаданского, Чиргакинского и Шеминского сельсоветов;

Каа-Хемский (с. Сарыг-Сеп) в составе рабочих поселков Бай-Сют, Харал и Бельбейского, Буренского, Бурен-Хемского, Ильинского, Коптинского, Сарыг-Сепского, Федоровского сельсоветов;

Кызылский (г. Кызыл) в составе Кара-Хаакского, Кок-Тейского, Сесерлигского, Талсинского и Эрбекского сельсоветов;

Монгун-Тайгинский (с. Мугур-Аксы) в составе Каргинского, Моген-Буренского, Мугур-Аксынского и Хурен-Тайгинского сельсоветов;

Овюрский (с. Хандагайты) в составе Дус-Дагского, Саглынского, Сольчурского, Хандагайтинского и Палатинского сельсоветов;

Пий-Хемский (г. Туран) в составе Баян-Кольского, Верхне-Тарлагского, Верхне-Уюкского, Нижне-Тарлагского, Нижне-Уюкского и Хутинского сельсоветов;

Сут-Хольский (с. Суг-Аксы) в составе Алдан-Маадырского, Бора-Тайгинского, Кызыл-Тайгинского, СугАксынского, Сут-Хольского, Улуг-Алакского, Хольчуктугского и Хор-Тайгинского сельсоветов;

Тандинский (с. Бай-Хаак) в составе Бай-Хаакского, Балгазынского, Кок-Булунского, Кочетовского, Межегейского, Успенского и Элегестинского сельсоветов;

Тере-Хольский (с. Чиргаланды) в составе рабочего поселка Эми и Балыктыгского, Каргинского, Шинанского, Чиргаландинского сельсоветов;

Тес-Хемский (с. Самагалтай) в составе Берт-Дагского, Кызыл-Чиранского, Оруку-Шинанского, Сама- 
галтайского, Усть-Шинанского, Чиргаландинского и Шуурмакского сельсоветов;

Тоджинский (с. Тоора-Хем) в составе Пий-Хемского, Одугенского, Оо-Хемского, Сейбинского, СистигХемского, Тора-Хемского, Улуг-Дагского и Хам-Саринского сельсоветов;

Улуг-Хемский (г. Шагонар) в составе Баян-Кольского, Ийи-Тальского, Кара-Булунского, Кок-Чиранского, Темир-Сугского, Торгалыкского, Хайыраканского, Хендергинского, Чаатинского, Шаган-Арыгского, Эжимского и Эйлиг-Хемского сельсоветов;

Чаа-Хольский (с. Чаа-Холь) в составе Ак-Туругского, Кара-Тальского, Кызыл-Дагского, Урбюнского, Хеременского, Чаа-Хольского и Шанчинского сельсоветов;

Эрзинский (с. Сарыг-Булун) в составе рабочего поселка Нарын и Бай-Дагского, Бай-Хольского, Качикского, Сарыг-Булунского, Тесинского, Тере-Хольского и Эрзинского сельсоветов (ГА РТ, ф. 264, оп. 1, д. 20, л.13-16, д. 23, л. 3-Зоб.; Путеводитель ... , 2012: 346-363).

В 1960-е гг. была продолжена работа по уточнению наименований некоторых населенных пунктов Тувинской АССР. По итогам проведенной работы был принят Указ Президиума Верховного Совета РСФСР от 23 октября 1963 г. (ГА РТ, ф. 285, оп. 1, д. 30, л. 222-223). Согласно данному указу почти во всех муниципальных районах Тувы названия муниципальных образований были переименованы.

Приведем отдельные именования, закрепленные не только в документах фонда 285 ГА РТ, но и в ознакомительных целях были опубликованы в «Путеводителе ...» в приложении, подготовленном В. А. Дубровским и М. Ш. Кууларом (Путеводитель, 1987: 182-188). Так, например, в Барун-Хемчикском районе было переименовано пять населенных пунктов: с. Ыйгылак было переименовано в с. Эрги-Барлык, с. Булун - в с. Шуй, с. Даспы-Аксы - в с. Кара-Холь, с. Биче-Тей - в с. Шекпээр. Здесь мы видим, что переименование было проведено и по территориальному, и по историко-этнографическому принципу. Необходимо подчеркнуть, что переименованы были многие муниципальные образования Тувы. Так, в Дзун-Хемчикском хошуне, в состав которого на тот период входил и современный Сут-Хольский кожуун, процесс затронул 8 поселений: с. Даштыг-Кужур - в с. Хондергей, с. Борбак-Арыг - в с. Шеми, с. Суг-Аксы - в с. Сут-Холь, с. Малгаш-Бажин - в с. Бора-Тайга, с. Ишкин-Аксы - в с. Ишкин, с. КокТерек - в с. Алдан-Маадыр, с. Кызыл-Чыраа - в с. Ийме, с. Булун-Терек - в с. Баян-Тала. Критерием также послужили не только территориальные признаки, но и значимость исторических событий, происходивших на территории муниципального образования, например, переименование с. Кок-Терек - в с. Алдан-Маадыр (в честь восстания шестидесяти богатырей 1883-1885 гг.). Интересно, что переименование русских населенных пунктов на тувинский язык было продолжено и в 1960-е гг. Примером тому является Каа-Хемский район, где с. Медведевка было переименовано в с. Кок-Хаак, а пос. Даниловка - в пос. Дерзиг-Аксы, пос. Мергенъ - в пос. Мерген (исправлено правописание), с. Федоровка - в с. Кундустуг, пос. Саваганды - в пос. Бай-Соот. Аналогичный процесс наблюдается в переименовании населенных пунктов Пий-Хемского района: пос. Сейба - в пос. Севи, с. Сушъ - в с. Суш.

Далее мы приводим переименования, проведенные в Тандинском районе, где с. Алаак было переименовано в с. Межегей, пос. Хаак - в пос. Каък, пос. Ангачи - в пос. Онгача, с. Суг-Бажи - в с. Целинное, пос. Сук-Пак - в пос. Сукпак, с. Балгазик - в с. Балгазын, пос. Тубсанаторий - в пос. Сой. В Тес-Хемском районе было переименовано 4 населенных пункта: с. Теректиг-Хем - в с. Берт-Даг, пос. Холл-оожу в пос. Холь-оожу, с. Сарыг-Булун - в с. Эрзин, с. Хондей-Аксы - в с. Нарын. Здесь видно, что наименования были изменены не только потому, что изменился принцип, которым руководствовались, но и просто вносились исправления, связанные с написанием тувинских слов на русском языке, где-то просто были возвращены прежние именования, где-то был выбран другой маркирующий географический объект. В Улуг-Хемском районе было переименовано 9 муниципальных образований: пос. КокЧира - в с. Кок-Чыраа, пос. Алды-Шынаа - в пос. Алдыы-Шынаа, пос. Баянкол - в с. Баян-Кол, с. Зеленая Роща - в с. Чодураа, пос. Ходжей - в пос. Кожай, пос. Ишти-Хем - в пос. Иштии-Хем, пос. Араксан - в пос. Арыскан, пос. Белдир-Кежи - в пос. Белдир-Кежиг, пос. Шанчи - в пос. Шанчы. Здесь мы видим, что переименование было проведено исходя из принципов правописания, замена названий с русского на тувинский язык в соответствии с отличительным географическим признаком. В Тоджинском районе в связи с исправлением правописания было переименовано только с. Усть-Систиг-Хем в с. Сыстыг-Хем (Путеводитель ..., 2012: 346-363).

В тексте Указа Президиума Верховного Совета РСФСР от 3 февраля 1964 г. (ГА РТ, ф. 285, оп. 1, д. 49, л. 16) встречается именование города районного подчинения - Ак-Довурак, что в переводе с тувинского языка обозначает «белый песок». Здесь мы видим, что в наименовании был использован географический признак, связанный с месторождением асбеста и цветовым маркером. 
Процесс районирования был продолжен и в конце 1960-х - начале 1970-х гг., однако в этот раз основным критерием стала рационализация управленческих задач, что потребовало выделения из укрупненных муниципальных районов отдельных территорий. Таким образом были восстановлены некоторые районы. Например, Указом Президиума Верховного Совета РСФСР от 12 января 1965 г. были разукрупнены Барун-Хемчикский и Тес-Хемский районы и образованы Бай-Тайгинский и Эрзинский районы. Таким образом, стало 4 района. Этим же указом города Тувы были введены в районное подчинение, например в состав Барун-Хемчикского района включен г. Ак-Довурак, Дзун-Хемчикского г. Чадан, Пий-Хемского - г. Туран, Улуг-Хемского - г. Шагонар (Путеводитель ..., 2012: 346-363).

В соответствии с Указом Президиума Верховного Совета РСФСР от 9 сентября 1968 г. образован Монгун-Тайгинский район в составе сел Мугур-Аксы и Кызыл-Хая (ГА РТ, ф. 285, оп. 1, д. 137, л. 211).

В том же году Указом Президиума Верховного Совета Тувинской АССР от 3 декабря 1975 г. на территории Баян-Кольского сельсовета Кызылского района был зарегистрирован населенный пункт пос. Терлиг-Хая (ГА РТ, ф. 285, оп.1, д. 352, л. 284).

Указом Президиума Верховного Совета РСФСР от 25 апреля 1983 г. образован Сут-Хольский район за счет разукрупнения Дзун-Хемчикского (ГА РТ, ф. 285, оп. 1, д. 6, л. 33).

Указом Президиума Верховного Совета Тувинской АССР от 9 марта 1988 г. в Улуг-Хемском районе образован Эйлиг-Хемский сельсовет с административным центром в селе Эйлиг-Хем (ГА РТ, ф. 270, оп. 1, д. 1272, л. 36).

Указом Верховного Совета Тувинской АССР от 11 марта 1990 г. в Овюрском районе был образован Сарыг-Хольский сельсовет (ГА РТ, ф. 285, оп. 1, д. 47, л. 77).

Постановлением Верховного Совета Республики Тыва от 20 декабря 1991 г. с 1 января 1992 г. образован Чаа-Хольский район Республики Тыва (ГА РТ, ф. 28, оп.1, д. 67, л. 10).

Архивные документы советского этапа свидетельствуют о продолжении процессов районирования в Туве. Также документы фиксируют переименования названий муниципальных образований, связанные с уточнением правописания.

\section{Наименования муниципальных образований в 1992-2005 22.}

Четвертый этап начался в 1992 г. и характеризуется очередным переименованием наименований, связанным с изменением идеологических установок, созданием новых государственных институтов, демократизацией общественно-политической жизни, значительными преобразованиями в экономике, например, исчезновением совместных и коллективных хозяйств и, следовательно, этих именований.

Указом Президиума Верховного Совета Республики Тыва от 21 декабря 1992 г. за счет частей территории Тандинского и Улуг-Хемского районов образован Чеди-Хольский район с центром в р. п. ХовуАксы (Путеводитель..., 2011: 354).

Постановлением Верховного Хурала Республики Тыва от 20 мая 1994 г. старый п. Хову-Аксы отделен от кожунного центра п. г. т. Хову-Аксы, и на его базе образован сумон Сайлыг с административным центром в селе Сайлыг с приданием статуса сумона кожуунного подчинения (ГА РТ, ф. 846, оп.1, д. 3, л. 112).

Постановлением Верховного Хурала Республики Тыва от 23 мая 1994 г. в составе Эрзинского кожууна образован сумон Качык (ГА РТ, ф. 846, оп.1, д. 3, л. 127).

Постановлением Верховного Хурала Республики Тыва от 27 октября 1994 г. образован сумон Бижиктиг-Хая Барун-Хемчикского кожууна с административным центром в с. Бижиктиг-Хая с приданием ему статуса сумона кожуунного подчинения (ГА РТ, ф. 846, оп.1, д. 7, л. 9).

Постановлением Верховного Хурала (парламента) Республики Тыва от 19 июля 2001 г. образован Тере-Хольский кожуун Республики Тыва с центром в селе Кунгуртуг (ГА РТ, ф. 846, оп. 1, д. 94, л. 141). В административные территории данного кожууна включены земли Шынаанского сумона и бывших совхозов, сельских поселений Эми, Балыктыг, Каргы, Чыргаланды, а также иные земли согласно карте и ее письменного описания.

Постановлением Верховного Хурала (парламента) Республики Тыва от 20 февраля 2002 г. внесено дополнение в постановление Верховного Хурала (парламента) Республики Тыва от 19 июля 2001 г. (пункт 5) о включении в состав образуемого Тере-Хольского кожууна Шынаанской сумонной администрации Кызылского кожууна (Путеводитель ..., 2011: 355). 
Конституционным законом Республики Тыва от 28 декабря 2005 г., принятым Законодательной палатой и одобренным Палатой представителей, в Тере-Хольском кожууне Республики Тыва образованы следующие административно-территориальные единицы: 1) сумон Балыктыг с административным центром в селе Тал; 2) сумон Каргы с административным центром в селе Белдир-Чазы; 3) сумон Эми с административным центром в селе Оттук-Даш (там же: 355).

В соответствии с Реестром административно-территориального деления Республики Тыва, который утвержден постановлением Законодательной палаты и Палаты представителей Великого Хурала РТ от 21 декабря 2005 г. № 1648 ЗП-1, Республика Тыва на сегодня насчитывает 17 кожуунов (муниципальных районов), 5 городов (Кызыл, Ак-Довурак - республиканского подчинения, Чадан (Чадаана), Туран, Шагонар (Шагаан-Арыг) - кожуунного подчинения, 1 поселок городского типа (Каа-Хем), 119 сумонов (ГА РТ, ф. 846, оп. 1, д. 273, л. 155-161).

Поводя итоги обзора данного этапа, хотелось бы подчеркнуть, что его хронологические рамки не ограничены 2005 годом, он продолжается по настоящее время. «Граница» 2005 г. нами указана условно в связи с изученными архивными документами, датировка которых завершается 2005 годом. В целом документы данного этапа фиксируют современные социокультурные процессы возрождения национальной культуры и национальной идентичности.

\section{Заключение}

Архивные документы по именованиям муниципальных образований Тувы разных лет являются свидетелями всех политических и социокультурных процессов, которые пережил тувинский народ с 1759-2005 годы. Поскольку изученные нами документы являются результатом фиксирования решения, принятого органами власти и управления, следовательно, наименования в архивных источниках отражают государственной политики в сфере формирования и развития административно-территориального деления Тувы, партийно-идеологические установки.

В целом, документы показывают, что проблема районирования в виде поиска оптимального количества муниципальных образований и состава муниципальных районов, отвечающих интересам государства, на всех этапах развития истории тувинской государственности оставалась актуальной. Переименования муниципальных образований, вызванные стремлением упорядочить и систематизировать названия районов, городов, сел и других поселений Тувы, проводились в соответствие с принятыми на тот период языковыми нормами.

\section{СПИСОК ЛИТЕРАТУРЫ}

Бавуу-Сюрюн, М. В. (2005) Структура топонимов монгольского происхождения на территории Тувы // Проблемы этнокультурых связей монгольских и тюркских народов / Сампилдэндэв Х. и др., отв. ред. А.Л. Ангархаев. УланУдэ : ГУП «ИД «Буряад үнэн». 351 с. С. $233-237$.

Бавуу-Сюрюн, М. В. (2018) Топонимы как маркеры диалектов и говоров тувинского языка [Электронный ресурс] // Новые исследования Тувы. № 3. URL: https://nit.tuva.asia/nit/article/view/786 (дата обращения 24.01.2020). DOI: https://www.doi.org/10.25178/nit.2018.3.2

Бадарч, Б., Бавуу-Сюрюн, М. В. (2018) Монголизмы в тувинских топонимах: сопоставительный анализ географических названий сумона Цэнгэл Баян-Улэгэйского аймака Монголии и Тувы [Электронный ресурс] // Новые исследования Тувы. № 3. URL: https://nit.tuva.asia/nit/article/view/799 (дата обращения 20.01.2020). DOI: https://www. doi.org/10.25178/nit.2018.3.14

Биче-оол, Т. Н., Допчут А. А. (2015) Изменение административно-территориального деления Республики Тыва // Вестник Байкальского государственного университета. № 9 (124). С. 4-9.

Бруннерт, И. С., Гагельстром, В. В. (1910) Современная политическая организация Китая. Пекин : Тип. Успен. монастыря при Рус. духов. миссии. 380 с.

Грумм-Гржимайло, Г. Е. (1926) Западная Монголия и Урянхайский край : в 2 т. Л. : Изд-во Гос. Рус. геогр. об-ва. T. 3. Вып. 1. Антропологический и этнографический очерк этих стран. 413 с.

Дулов, В. И. (1956) Соцаильно-экономическая история Тувы (XIX - начало XX в.). М. : Издательство Академии наук СССР. 608 с.

История Тувы (2007) / под общ. ред. В. А. Ламина. Новосибирск : Наука. Т. II. 430 с.

Катанов, Н. Ф. (2011) Очерки Урянхайской земли. Дневник путешествия, исполненного в 1889 году по поручению императорской академии наук и императорского русского географического общества / отв. ред. К. А. Бичелдей. Кызыл : ТИГИ при Правительстве РТ. 383 с.

Кара-оол, Л. С. (2018) Лексические особенности топонимов Овюрского района Тувы [Электронный ресурс] // Новые исследования Тувы. № 3. URL: https://nit.tuva.asia/nit/article/view/795 (дата обращения 16.01.2020). DOI: https://www.doi.org/10.25178/nit.2018.3.11 
Кара-оол, Л. С. (2019а) Лексика родильных обрядов в топонимии Тувы // Мир науки, культуры и образования. Вып. 3 (76). С. 368-369.

Кара-оол, Л. С. (2019b) Числительные в топонимах Тувы // Oriental Studies. № 4(44). С. 691-706. DOI: https://doi. org/10.22162/2619-0990-2019-44-4-691-706б

Каррутерс, А. Д. (1914) Неведомая Монголия. Т. 1. Урянхайский край. Петроград : Изд-во переселенческого управления Главного управления землеустройства и земледелия. 341 с.

Липовцев, С. В. (1828) Уложение Китайской палаты внешних сношений / пер. с маньчжур. Т. І. СПб. : Тип. Деп. нар. просвещения. 362 с.

Ондар, Б. К. (2007) Топонимический словарь Тувы. 2-е изд. Кызыл : Тувинское книжное издательство. 550 с.

Ондар, Б. К. (2008) Тувинская топонимия. Сопоставительный анализ топонимии Тувы с топонимией Южной Сибири и других тюркоязычных территорий. Кызыл : Тувинское книжное издательство 304 с.

Ондар, Б. К. (2011) Русская топонимия Тувы. Кызыл : Редакционно-издательский отдел ТувГУ. 168 с.

Потанин, Г. Н. (1883) Очерки Северо-Западной Монголии. СПб. : Тип. В. Киршбаума. 372 с.

Потапов, Л. П. (1969) Очерки народного быта тувинцев. М. : Наука. 402 с.

Путеводитель по фондам Центрального государственного архива Тувинской АССР. Состав и содержание фондов 1756-1986 гг. (1987) / ред. кол.: В. А. Бузыкаев, Л. С. Дробяцких, Б. Ч. Ширин-оол. Кызыл : Тувинское кн. изд-во. $221 \mathrm{c}$.

Путеводитель по фондам Государственного архива Республики Тыва за 1715-2011 гг. (2012) / сост. А. М. ДугарСюрюн, Т. А. Бондаренко, М. Ш. Куулар, Н. И. Сургутская. 2 изд., перераб. и доп. Новосибирск : Сибирское кн. издво. 460 c.

Сат, Ш. Ч. (1969) Заметки по топонимии Тувы // Материалы конференции «Этногенез народов Северной Азии» / отв. ред. Е. И. Убрятова. Вып. 1. Новосибирск: б/и. 247 с. С. 232-234.

Сувандии, Н. Д. (2019) Топонимы-цветообозначения в тувинском языке [Электронный ресурс] // Новые исследования Тувы. № 4. URL: https://nit.tuva.asia/nit/article/view/896 (дата обращения: 20.01.2020). DOI: https://www. doi.org/10.25178/nit.2019.4.16

Татаринцев, Б. И. (1973) Об особенностях топонимии Северо-Восточной Тувы // Происхождение аборигенов Сибири и их языков. Материалы Всесоюзной конференции 14-16 июня 1973 г. / редкол.: Э. Г. Беккер и др. Томск : Издательство Томского университета. 235 с. С. 142-144.

Татаринцев, Б. И. (1977) Местные географические термины Северо-Восточной Тувы // Советская тюркология / глав. ред. М. Ш. Ширалиев. Баку: Типография имени 26 бакинских комиссаров, 1977. Вып. 5. 113 с. С. $18-26$.

Татаринцев, Б. И. (1993) О некоторых древних топонимах тюркского происхождения на территории Тувы // Вопросы тувинского языкознания / отв. ред. Д. А. Монгуш, Б. И. Татаринцев. Кызыл : Новости Тувы. 126 с. С. $105-113$.

Ховалыг, С. С. (2006) Административно-территориальное устройство Тувы во второй половине XVIII - в начале $\mathrm{XX}$ в. // Ломоносовские чтения 2005: Стратегии развития гуманитарных технологий в постдипломном образовании в России и за рубежом / под общ. ред. Л. Н. Панковой. М. : Теис. 470 с. С. 393-397.

Ховалыг, С. С. (2019) Институт зайсанства в традиционном тувинском обществе: история и трансформация в середине XVIII - начале XX в. // Oriental Studies. № 45(5). C. 761-770. DOI: https://www.doi.org/10.22162/2619-09902019-45-5-761-770

Дата поступления: 02.02.2020 г.

\section{REFERENCES}

Bavuu-Surun, M. V. (2005) Struktura toponimov mongol'skogo proiskhozhdeniia na territorii Tuvy [The structure of toponyms of Mongol origin on the territory of Tuva]. In: Problemy etnokul'turnykh sviazei mongol'skikh i tiurkskikh narodov [Problems of ethnocultural links between Mongol and Turkic peoples] / Sampildendev Kh. et al. ; ed. by A. L. Angarkhaev. UlanUde, GUP «ID «Buriaad ynen». 351 p. Pp. 233-237. (In Russ.).

Bavuu-Surun, M. V. (2018) Toponimy kak markery dialektov i govorov tuvinskogo iazyka [Place names as markers of the dialects and sub-dialects of Tuvan language]. The New Research of Tuva, no. 3 [online] Available at: https://nit.tuva.asia/ nit/article/view/786 (access date 24.01.2020). (In Russ.). DOI: https://doi.org/10.25178/nit.2018.3.2

Badarch, B. and Bavuu-Surun, M. V. (2018) Mongolizmy v tuvinskikh toponimakh: sopostavitel'nyi analiz geograficheskikh nazvanii sumona Tsengel Baian-Ulegeiskogo aimaka Mongolii i Tuvy [Mongolisms in Tuvan toponyms: a comparative analysis of placenames in Tsengel sum of Bayan-Olgii aimag, Mongolia with those of Tuva]. The New Research of Tuva, no. 3 [online] Available at: https://nit.tuva.asia/nit/article/view/799 (access date 20.01.2020). (In Russ.). DOI: https://doi.org/10.25178/nit.2018.3.14

Biche-ool, T. N. and Dopchut A. A. (2015) Izmenenie administrativno-territorial'nogo deleniia Respubliki Tyva [Change in the administrative territorial division Republic of Tuva]. Vestnik Baikal'skogo gosudarstvennogo universiteta, no. 9 (124), pp. 4-9. (In Russ.).

Brunnert, I. S. and Gagel'strom, V. V. (1910) Sovremennaia politicheskaia organizatsiia Kitaia [Political organization of contemporary China]. Beijing, Tip. Uspen. monastyria pri Rus. dukhov. missii. 380 p. (In Russ.).

Grum-Grzhimailo, G. E. (1926) Zapadnaya Mongoliya i Uryanhaiskii krai [Western Mongolia and the Uriankhai Territory]. Vol. 3. Part 1. An anthropological and ethnographical sketch of these countries by G. Grum-Grzhimailo. Leningrad, State (Russian) Geographical Society. 412 p. (In Russ.). 
Dulov, V. I. (1956) Sotsial'no-ekonomicheskaia istoriia Tuvy. XIX - nachalo XX v. [The socio-economic history of Tuva, XIX - early XX centuries]. Moscow, Akademia nauk SSSR Publ. 608 p. (In Russ.).

Istoriia Tuvy [The History Of Tuva] (2007): in 3 vols. / ed. by V. A. Lamin. Novosibirsk, Nauka. Vol. 2. 430 p. (In Russ.).

Katanov, N.F. (2011) Ocherki uriankhaiskoi zemli. Dnevnik puteshestviia, ispolnennogo $v 1889$ godu [Essays on the Uriankhai Territory. Diary of a journey made in 1889]. Preparation of the manuscript for printing, introduction and commentary by A. K. Kuzhuget. Kyzyl, TIGPI pri Pravitel'stve RT. 383 p. (In Russ.).

Kara-ool, L. S. (2018) Leksicheskie osobennosti toponimov Oviurskogo raiona Tuvy [Lexical features of microtoponyms of Ovyur rayon of Tuva]. The New Research of Tuva, no. 3 [online] Available at: https://nit.tuva.asia/nit/article/view/795 (access date 16.01.2020). (In Russ.). DOI: https://doi.org/10.25178/nit.2018.3.11

Kara-ool, L. S. (2019a) Leksika rodil'nykh obriadov v toponimii Tuvy [Lexics of maternal rites in toponyms of Tuva]. Mir nauki, kul'tury i obrazovaniia, vol. 3 (76), pp. 368-369. (In Russ.).

Kara-ool, L. S. (2019b) Chislitel'nye v toponimakh Tuvy [Numerals in Toponyms of Tuva]. Oriental Studies, no. 4(44), pp. 691-706. (In Russ.). DOI: https://doi.org/10.22162/2619-0990-2019-44-4-691-706

Carruthers, A. D. (1914) Nevedomaia Mongoliia [Unknown Mongolia]. Vol. 1. Uriankhai Territory. Petrograd, publishing house of the Migration Department of the Main Department of land management and agriculture. 341 p. (In Russ.).

Lipovtsev, S. V. (1828) Ulozhenie Kitaiskoi palaty vneshnikh snoshenii [The Code of the Chinese Chamber of External Relations] / translated from Manchur. Vol. I. St. Petersburg, Tip. Dep. nar. prosveshcheniia. 362 p. (In Russ.).

Ondar, B. K. (2007) Toponimicheskii slovar' Tuvy [A toponymical dictionary of Tuva]. 2nd ed. Kyzyl, Tuvan book publisher. 550 p. (In Russ.).

Ondar, B. K. (2008) Tuvinskaia toponimiia. Sopostavitel'nyi analiz toponimii Tuvy s toponimami Iuzhnoi Sibiri i drugikh tiurkoiazychnykh territorii [Tuvan toponyms. A comparative analysis of toponyms of Tuva with those of southern Siberia and other Turkic-speaking territories]. Kyzyl, Tuvan book publisher. 296 p. (In Russ.).

Ondar, B. K. (2011) Russkaia toponimiia Tuvy [Russian placenames in Tuva]. Kyzyl, Redaktsionno-izdatel'skii otdel TuvGU. 168 p. (In Russ.).

Potanin, G. N. (1883) Ocherki Severo-Zapadnoi Mongolii. Materialy etnograficheskie [Essays Of North-Western Mongolia: Ethnographic Materials]. St. Petersburg, V. Kirshbaum. IV, 1026 p. (In Russ.).

Potapov, L. P. (1969) Ocherki narodnogo byta tuvintsev [The Tuvans: sketches of the folk lifestyle and related household activities]. Moscow, Nauka, GRVL. 402 p. (In Russ.).

Putevoditel' po fondam Tsentral'nogo gosudarstvennogo arkhiva Tuvinskoi ASSR. Sostavi soderzhanie fondov 1756-1986 gg. [The guide to the funds of the Central State Archive of the Tuvan ASSR. Composition and structure of collections, 1756-1986] (1987) / editorial board V. A. Buzykaev, L. S. Drobiatskikh and B. Ch. Shirin-ool. Kyzyl, Tuvan book publ. 221 p. (In Russ.).

Putevoditel' po fondam Gosudarstvennogo arkhiva respubliki Tyva [The guide to the collections of the State Archives of the Republic of Tuva] (2012). 2nd ed. Novosibirsk, Sibirskoe knizhnoe izd-vo. 460 p. (In Russ).

Sat, Sh. Ch. (1969) Zametki po toponimii Tuvy [Notes on the toponymy of Tuva]. In: Materialy konferentsii «Ehtnogenez narodov Severnoj Azii» [Ethnogenesis of peoples of Northern Asia: Proceedings of a conference], ed. by E. I. Ubryatova. Novosibirsk, s. n. Pp. 232-234. (In Russ.).

Suvandii, N. D. (2019) Place names of color designation in Tuvan language. The New Research of Tuva, no. 4 [online] Available at: https://nit.tuva.asia/nit/article/view/896 (access date 16.01.2020). (In Russ.). DOI: https://doi.org/10.25178/ nit.2019.4.16

Tatarintsev, B. I. (1973) Ob osobennostiakh toponimii severo-vostochnoi Tuvy [About the peculiarities of toponyms of North-Eastern Tuva]. In: Proiskhozhdenie aborigenov Sibiri i ikh iazykov [The origin of aboriginal peoples of Siberia and their languages] : Proceedings of All-Union conference, June 14-16, 1973]. Tomsk, Tomskii un-t Publ. 236 p. Pp. 142-144. (In Russ.).

Tatarintsev, B. I. (1977) Mestnye geograficheskie terminy severo-vostochnoi Tuvy [Local geographical terms of NorthEastern Tuva]. In: Sovetskaia tiurkologiia [Soviet Turkology]. Vol. 5. / Ed. by M. Sh. Shiraliev. Baku, Tip-ia im. 26-ti bakinskikh komissarov. 112 p. Pp. 18-26. (In Russ.).

Tatarintsev, B. I. (1993) O nekotorykh drevnikh toponimakh tyurkskogo proiskhozhdeniya na territorii Tuvy [On some ancient toponyms of Turkic origin in the territory of Tuva]. In: Voprosy tuvinskogo yazykoznaniya [Questions of Tuvan linguistics] / ed. by D. A. Mongush and B. I. Tatarincev. Kyzyl, Tuvinskii nauchno-issledovatel'skii institut yazyka, literatury i istorii. 128 p. Pp. 105-112. (In Russ.).

Khovalyg, S. S. (2006) Administrativno-territorial'noe ustroistvo Tuvy vo vtoroi polovine XVIII - v nachale XX v. [Territorial division of Tuva in the second half of the XVIII - early XX century]. In: Lomonosovskie chteniia 2005: Strategii razvitiia gumanitarnykh tekhnologii v postdiplomnom obrazovanii v Rossii i za rubezhom [Lomonosov readings 2005: Strategies for the development of humanitarian technologies in postgraduate education in Russia and abroad] / ed. by L. N. Pankova. Moscow, Teis. 470 p. Pp. 393-397. (In Russ.).

Khovalyg, S. S. (2019) Institut zaisanstva v traditsionnom tuvinskom obshchestve: istoriia i transformatsiia v seredine XVIII - nachale XX v. [Zaysanism in Traditional Tuvan Society: History and Transformation in the Mid-18th - Early 20th Centuries]. Oriental Studies, no. 45(5), pp. 761-770. DOI: https://doi.org/10.22162/2619-0990-2019-45-5-761-770 